\title{
Rh Isoimmunized Pregnancy-Do Maternal Antibody Titre Always Correlate with the Fetal Affection? A Non-Invasive Management
}

\author{
Divyesh V. Shukla, Shilpi D. Shukla, Ajay Valia, Yesha Chokshi \\ Isha Hospital, Sarabhai Campus, Vadodara, India \\ Email: divyeshshukla@yahoo.com
}

How to cite this paper: Shukla, D.V., Shukla, S.D., Valia, A. and Chokshi, Y. (2018) Rh Isoimmunized Pregnancy-Do Maternal Antibody Titre Always Correlate with the Fetal Affection? A Non-Invasive Management. Open Journal of Obstetrics and Gynecology, 8, 170-174.

https://doi.org/10.4236/ojog.2018.83020

Received: December 21, 2017

Accepted: March 6, 2018

Published: March 9, 2018

Copyright $\odot 2018$ by authors and Scientific Research Publishing Inc. This work is licensed under the Creative Commons Attribution International License (CC BY 4.0).

http://creativecommons.org/licenses/by/4.0/

\begin{abstract}
This case is of $\mathrm{Rh}-\mathrm{ve} 2^{\text {nd }}$ gravida having antibody titre detected $1: 2$ at 8 weeks of $2^{\text {nd }}$ pregnancy. Serial antibody titre carried out along with clinical examination. Fetal monitoring was done by assessing MCA-PSV (Middle cerebral artery peak systolic velocity) and CTG (Cardiotocograph) when required. Pregnancy was terminated when the titre reached 1:512 at 34 wks of pregnancy with abnormal MCA-PSV values. Neonate just had begun to show sign of anaemia \& haemolysis at birth.
\end{abstract}

\section{Keywords}

$\mathrm{Rh}-\mathrm{Ve}, \mathrm{Rh}+\mathrm{Ve}, \mathrm{MCA}-\mathrm{PSV}, \mathrm{CTG}, \mathrm{Rh}$ Isoimmunization, Rh Antibody Titre

\section{Background}

Managing $\mathrm{Rh}$ Isoimmunized pregnancy is an obstetric challenge and it is necessary to timely terminate the pregnancy. It has been observed that antibodies formed in maternal circulation may cross the placental barrier in variable amount. This finally decides the state of fetal anaemia. Maternal antibody titres tend to correlate more reliably with the severity of fetal disease in the $1^{\text {st }}$ sensitized pregnancy than in subsequent pregnancies. Higher Rh antibody titres in this case did not correspond to fetal haemolytic disease although this was $1^{\text {st }}$ sensitized pregnancy for her. With history of a previous sensitization subsequent fetus are affected in $>80 \%$ cases. Here, maternal Rh titers are not predictive for the severity of fetal anaemia [1].

Non-invasive method by Colordoppler USG measuring MCA-PSV may be considered a standard method for fetal surveillance instead of invasive amni- 
ocentesis which was used earlier. This case report describes interpretation of antibody titre \& non-invasive management.

\section{Case Presentation}

A 28-year O Rh -ve patient $2^{\text {nd }}$ gravida para 1 had presented with 8 weeks pregnancy. She had a full term normal delivery 5 yrs back. There was no history of anti-Dad ministered post-delivery. Father was B Rh +ve homozygous. Her vitals were normal. Important investigations were blood group $\mathrm{O} \mathrm{Rh}-\mathrm{ve}$, normal complete blood count \& TSH levels, negative screening test for GDM. ICT (indirect Coombs test) was found to be positive but titer was 1:2. First trimester USG was normal. She was prescribed tablet folic acid $5 \mathrm{mg}$ and was advised regular antenatal follow up. Double marker screen was negative at 11 weeks. At 18 weeks iron and calcium supplementation were initiated. At 20 weeks patient had normal anomaly scan with length of cervix $35 \mathrm{~mm}$. ICT titers were done monthly until 24 wks \& than every 2 wks. At $26+$ wks of pregnancy, her ICT was found to be positive in a dilution of 1:8. MCA-PSV was $19.98 \mathrm{~cm} / \mathrm{s}$, corresponding to $<1.0 \mathrm{MOM}, \mathrm{CPR}$ (cerebroplacental ratio) was normal. Single observer measured MCA-PSV values by maintaining angle of insonation 0 or $<10$ degree. Antenatal steroids were given at $30 \mathrm{wks}$. MCA-PSV values measured every 1 - 2 weekly were <1.0 MOM till 32 wks when it reached 1.12. From $32-34$ wks PSV increased to $>1.5 \mathrm{MOM}$ and Rh antibody titer increased to 1:512. (Table 1, Figure 1) Decision of delivery by cesarean section was taken as cervix was not favorable. She delivered a $2.075 \mathrm{~kg}$ female baby with a normal Apgar score \& reflexes. The baby was B Rh +ve with hemoglobin $12 \mathrm{~g} \%$ (15 - 21) PCV 35.1\% (45 - 75), platelet count 89,000/cc $(100,000$ - 450,000) with retic count $11.8 \%(2-7)$. Cord blood bilirubin was $3.11 \mathrm{mg} / \mathrm{dl}$ (up to 2 ) and direct Coombs test was positive.

After $24 \mathrm{hr}$ of birth baby's Hb was $13.5 \mathrm{~g} \%$ (15 - 21) PCV $40.5 \%$ (45 - 67), platelet count $285,000 / \mathrm{cc}$. $(210,000$ - 500,000) Serum bilirubin was $8.69 \mathrm{mg}$ (up to $12 \mathrm{mg}$ ). Now phototherapy was started. After 8 hours of double surface phototherapy serum bilirubin was 8.44 . IVIG $(1 \mathrm{gm} / \mathrm{kg})$ was given at 36 hours of life.

Table 1. Maternal ICT titers and fetal MCA-PSV values.

\begin{tabular}{cccccc}
\hline Date & $\begin{array}{c}\text { Gestational } \\
\text { age }\end{array}$ & $\begin{array}{c}\text { ICT } \\
\text { titer }\end{array}$ & $\begin{array}{c}\text { MCA } \\
\text { PSV cm/s }\end{array}$ & $\begin{array}{c}\text { MOM of value } \\
\text { of patient }\end{array}$ & $\begin{array}{c}\text { Median peak systolic } \\
\text { velocity for gestational age }\end{array}$ \\
\hline $21 / 3 / 17$ & 6 weeks & $1: 2$ & - & - & - \\
$7 / 4 / 17$ & 10 weeks & $1: 2$ & - & - & - \\
$26 / 5 / 17$ & 16 weeks & $1: 2$ & - & - & 33.65 \\
$5 / 8 / 17$ & 26 weeks & $\begin{array}{c}1: 8 \\
\text { (critical titer) }\end{array}$ & 19.98 & 0.59 & 41.65 \\
$2 / 9 / 17$ & 30 weeks & $1: 256$ & 32.69 & 0.80 & 44.45 \\
$14 / 9 / 17$ & 32 weeks & $1: 256$ & 49.82 & 1.12 & 48.77 \\
$25 / 9 / 17$ & 34 weeks & $1: 512$ & 81.76 & 1.67 & \\
\hline
\end{tabular}




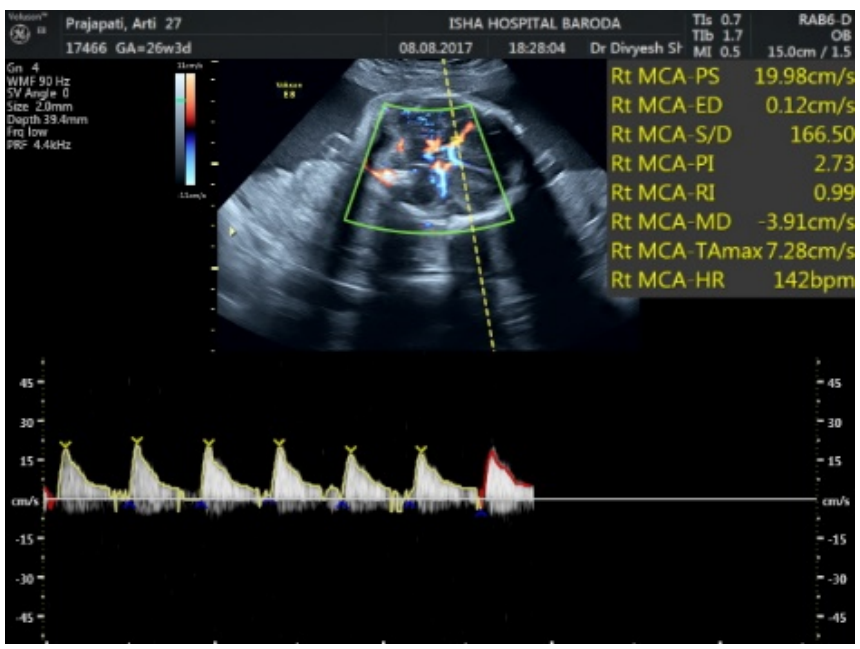

(a)

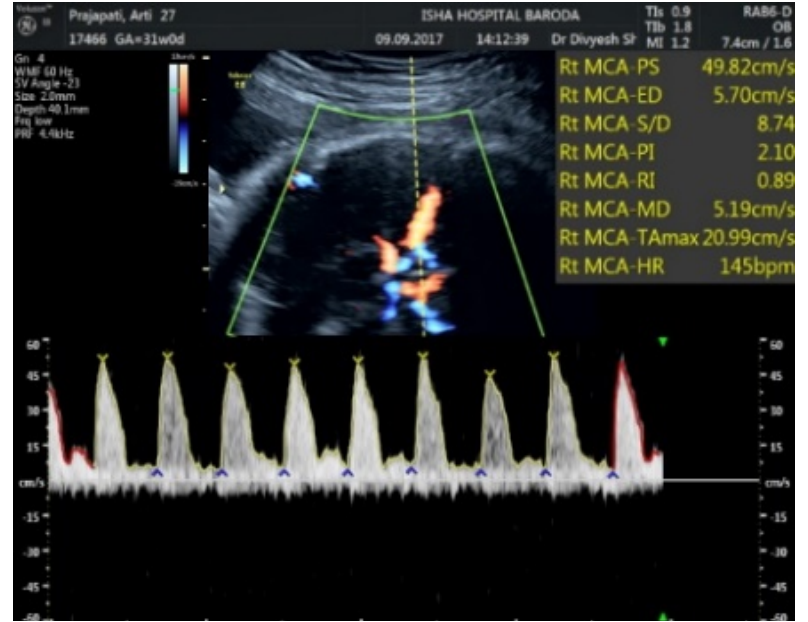

(b)

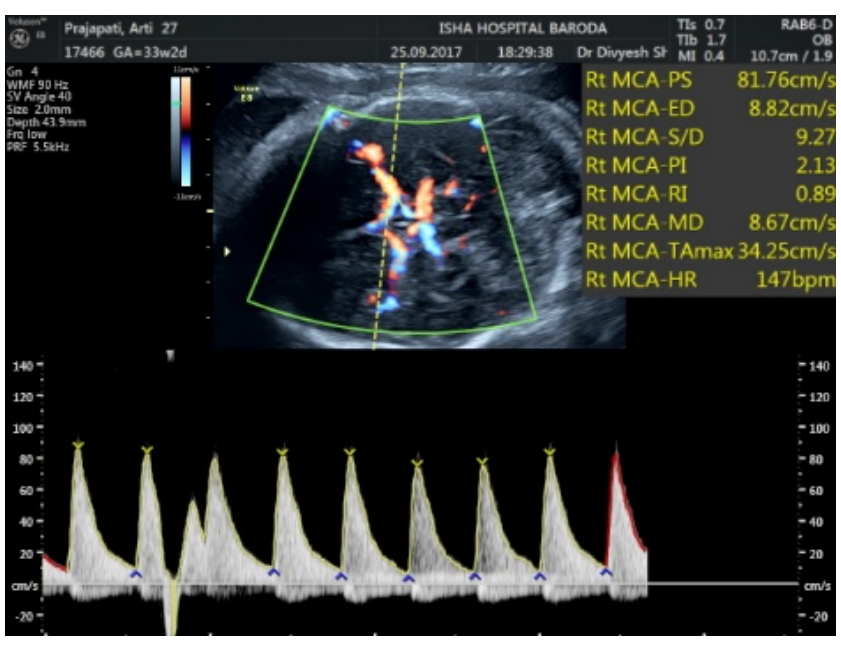

(c)

Figure 1. Color Doppler of fetal MCA-PSV serial assessment: (a) Colordoppler of MCA PSV at 26 weeks; (b) Colordoppler of MCA PSV at 32 weeks; (c) Colordoppler of MCA PSV at 34 weeks.

8 hours post IVIG s. Bilirubin decreased to $7 \mathrm{mg}$ and $\mathrm{Hb} 12.4 \mathrm{gm} \% \mathrm{PCV} 36 \%$ so phototherapy was omitted on day $5^{\text {th }}$ of life. Maximum serum bilirubin noted on $3^{\text {rd }}$ day of life $12.74 \mathrm{mg} .2^{\text {nd }}$ dose of IVIG $(1 \mathrm{gm} / \mathrm{kg})$ was given on $8^{\text {th }}$ day of life as $\mathrm{Hb}$ decreased. As the patient had RDS oxygen with prongs was given. USG brain was normal. Patient discharged on day $10^{\text {th }}$ of life with weight $1.960 \mathrm{~kg}$.

\section{Follow Up}

It was uneventful with normal rise in $\mathrm{Hb}$, weight \& other developmental parameters after $3^{\text {rd }}$ week.

\section{Discussion}

There is poor correlation between Rh antibody titres and severity of haemolytic disease especially in $2^{\text {nd }}$ sensitized pregnancy. With history of a previous anemic fetus or newborn, the probability of subsequent affected Rh D-incompatible fe- 
tus is more than $80 \%$ [2]. But similar poor correlation of antibody titer \& fetal anaemia was reported in this case without previous sensitized pregnancy. Serial $\mathrm{Rh}$ antibody titers along with MCA-PSV values were performed. MCA-PSV calculation was the only method to assess fetal anemia as it correlated well with fetal $\mathrm{Hb} \&$ delta OD 450 findings (Liley curve) [3]. Up to 34 wks sensitivity of detecting fetal anaemia is predicted $100 \%$ by MCA-PSV [4]. Fetal surveillance by CTG was performed. In this patient, the rising antibody titres were not correlated with fetal anaemia. USG additionally detects signs of fetal anemia. MCA-PSV are obtained from 18 wks to 35 wks of gestation, not after 35 wks as false +ve increases. The MCA is examined close to its origin in the internal carotid artery, angle of insonation should be 0 or $<10$ degree for accurate measurement of velocities [3]. As standard management fetal blood sampling by cordocentesis is done to assess fetal anemia, hematocrit \& acidosis. Hematocrit values $<30 \%$ obtained requires intrauterine transfusion up to $34 \mathrm{wks}$. The antibody titre below which there is no risk for hydrops fetalis or stillbirth before term is conventionally $1: 8$ to $1: 16$ [5]. In the case presented here, an anti-D antibody titre at 1:512 was associated with fetal anaemia \& haemolysis. There are several factors affecting transfer of maternal IGg across placenta, this can be the reason for non-correlation of fetal anaemia and antibody titre (maternal chronic infection, malnutrition, gestational diabetes, hypergammaglobulinemia, ABO incompatibility associated and IGg types) [6]. In view of this in the first and or in the subsequent sensitized pregnancies, the Rh antibody titer may not correlate with the severity of fetal affection.

\section{Learning Points}

MCA-PSV is important non-invasive test which correlates with fetal anaemia, delta OD 450 \& hyperdynamic fetal circulation. In this case of $\mathrm{Rh}$-ve mother even in $1^{\text {st }}$ sensitized pregnancy the high $\mathrm{Rh}$ antibody titres which were not indicative of fetal haemolysis as against previously reported fact that this happens only in $2^{\text {nd }}$ sensitized pregnancy.

\section{Conflict of Interest}

There was no conflict of interest \& due consent of the patient was taken to report her clinical case.

\section{References}

[1] Jain, D. (2017) Rh Isoimmunized Pregnancy Managed Noninvasively: A Report of Two Cases. International Journal of Applied and Basic Medical Research, 7, 73-76. https://doi.org/10.4103/2229-516X.198535

[2] Rapiti, S. and Carrara, S. (2009) Obstetric Management in Rh Alloimmunizated Pregnancy Alessandra Cacciatore. Journal of Prenatal Medicine, 3, 25-27.

[3] Piazze, J., Cerekja, A., et al. (2007) High Coombs Test Titers with No Fetal Anemia: Value of Middle Cerebral Artery Peak Systolic Velocity. Journal of the Turkish German Gynecological Association, 8. 
[4] Papantoniou, N. and Daskalakis, G. (2008) Increasing the Noninvasive Management of Rhesus Isoimmunization. International Journal of Gynaecology and Obstetrics, 101, 281-284. https://doi.org/10.1016/j.ijgo.2007.11.021

[5] Royal College of Obstetricians and Gynaecologists (2014) The Management of Women with Red Cell Antibodies during Pregnancy. Green-Top Guideline No. 65, Royal College of Obstetricians and Gynaecologists, London.

[6] Wilcox, C.R., Holder, B. and Jones, C.E. (2017) Factors Affecting the FcRn-Mediated Transplacental Transfer of Antibodies and Implications for Vaccination in Pregnancy. Frontiers in Immunology, 8, 1294.

https://doi.org/10.3389/fimmu.2017.01294 